\title{
INTERVIEW WITH ANGIE CARTER
}

\author{
INTERVIEW CONDUCTED BY: \\ WALTER GOETTLICH \\ University of Kansas
}

\begin{abstract}
Dr. Angie Carter, 2017 Blackmar Lecturer, is Assistant Professor of Environmental and Energy Justice at Michigan Technological University. Her work focuses on issues situated within environmental sociology, including agro-food systems, social inequity, social change and environmental justice. As the following conversation demonstrates, Dr. Carter is equally attentive to the significance of the participatory, community-based methodologies she employs, as well as the importance of doing public sociology in the current socio-political climate in the US. A selection of Dr. Carter's recent publication titles includes “'No Oil in Our Soil!': Shifting Narratives from Commodities to the Commons", "Changes on the Land: Gender and the Power of Alternative Social Networks", and "Placeholders and Changemakers: Women Farmland Owners Navigating Gendered Expectations.”
\end{abstract}

GOETTLICH: I would like to begin by acknowledging that this interview is being conducted on the traditional lands of the Kaw, Osage and Pawnee. This interview is part of the annual Blackmar Lecture Series hosted by the Sociology Graduate Student Association (SGSA) at KU, and co-sponsored this year by departments of American Studies, Anthropology, Environmental Studies, Geography and Atmospheric Science, and the KU Senate. Dr. Angie Carter, welcome.

CARTER: Thank you.

GOETTLICH: Your recent work focuses on the watershed, farmland, and community-level effects of the Bakken Pipeline extension through Iowa. Could you give me a summary of your project and its public implications? 
CARTER: In the summer of 2014 we found out about the Dakota Access Pipeline, or as it's known in Iowa, the Bakken Pipeline. In the summer of 2016, construction started, and so it's been almost three years now that I've been studying community reactions to the construction of the pipeline, what this means for private land owners, community members of the communities up and down the pipeline path in Iowa. My engagement in this project began first from personal interest. The pipeline was going right through the county that I was living in and would compromise the water supply for our town, and so that was my entryway into this.

Through getting to know more about people's concerns related to the pipeline, watching those people that would be coming to the public meetings, I became really interested in how concerned residents of Iowa were framing what they saw as problems with this pipeline. Prior to the pipeline's proposal I had been studying water quality in Iowa, which had become very contentious, very politicized. There was a lot of animosity towards the agricultural community from an urban perspective, and then people in agriculture complaining about people in urban areas not understanding the realities of agriculture. It had just reached an impasse where it was increasingly ridiculous in what was not happening in addressing this problem in our state.

In the midst of this, Dakota Access announced their plans for this pipeline, and so for the past almost three years I've been attending public meetings, whether it's through the Iowa Utility Board or at the county levels, community meetings that are hosted by nonprofits or landowner groups and following this in the news. I became really good friends with some of the landowners who are involved in the fight. My previous research for my dissertation studied land ownership in Iowa and conservation adoption. Some of the farmers who had been in my sample for my dissertation research were those along the pipeline path who were trying to figure out what to do now that they had received this letter that a pipeline was coming through their farms.

We have been trying to figure out since the start what the public implications are for this project because there was no environmental impact statement done--one was not required--and so no one had studied the environmental impacts. Of course, the environmental impacts are also social impacts because if a community's water 
source is compromised, if the fertility of farmland is compromised, those are also social problems. We really don't know the extent of the implications in Iowa, but from having studied history and looking at pipelines of this size and magnitude and scale across the country, we can see what happens.

In January of 2015, there was a new pipeline underneath the Yellowstone River in Montana. It was a new pipeline. It had been well maintained. They had built it how they were supposed to build it, but it was under the Yellowstone River. We know that the beds of rivers shift and change. In Iowa, we increasingly have more frequent rain and more intense storms, and so our rivers are changing at a scale that we haven't seen historically.

This pipeline beneath the Yellowstone River ruptured and contaminated the City of Glendive, Montana's water source with benzene, which is a cancer-causing agent. They're still--a couple years later--following up and cleaning up and trying to figure out what happened with that pipeline. We don't have to look too far back in time to see that the implications of these projects are very scary, I think, for ecological reasons but also for social reasons, talking about public health, financial impacts to these communities to have to deal with what do you do when your water supply has been contaminated with benzene. There are just many implications, and they've not been studied.

I have been studying the shift in discourse and how the narratives have changed from these communities in talking about water, land, and soil as public goods...rather than framing them as a very localized or individualized concern, talking about it more in this public frame that everyone lives downstream. Future generations are going to rely upon the soil for their livelihood, and we need to protect those things.

GOETTLICH: You mentioned 'community' a few times. I'm wondering, what does that mean to you, and if at all, how has that meaning changed over the course of your research?

CARTER: Well, I'm using community in the Leopoldian sense, drawing on Aldo Leopold's work and the land ethic. He's not a sociologist, but I think that his understanding of the relationship that humans have in the natural world and the symbiotic relationship 
there was a precursor to the rise of environmental sociology. While he may not get credit for being one of the forbearers of environmental sociology, I include him in my family of environmental sociologists.

When I say 'community' I'm thinking in a classical sociological sense about the people who live in a place, the aspects of community, whether it's church or these environmental concerns or the educational institutions there that are bringing people together. But I'm also expanding that to think about water, to think about soil, to think about the natural world and the environment and thinking about these things in relationship together when I'm talking about community.

GOETTLICH: In this sense, the coalitions that have come together over the Bakken Pipeline, are they potential community building exercises?

CARTER: Yes, and I think it's been really interesting seeing how that has happened over the past three years. In rural Iowa, there's been a lot of loss of population. Really, since the Farm Crisis of the 1980s, rural communities have not been doing very well in Iowa. To see a meeting in rural Iowa about what I would call an environmental issue have 100 people turn out on a week night when people usually are busy with their kids or taking care of their parents or just whatever, I think that that's a positive sign. People come because they're concerned about their farm or their neighbors or what's going to happen to their taxes if the pipeline breaks and their county has to clean it up.

They come maybe for an individual concern, but that they keep showing up at these meetings. They travel a couple hours on winter roads when there's a storm to go to Des Moines to give testimony at the capitol, or to show up at the Iowa Utility Board hearings. Something is moving them that's bigger than just their own concern-the unlikely alliances that have been forming at those meetings where there are people sitting side by side who normally don't go to meetings together. Environmentalists and farmers in Iowa historically have not had a very positive relationship together, so that has been really interesting to see that community form together around a common cause, even though people are coming to the table 
for different reasons, everybody agreeing that we don't need the pipeline.

Through the creation of that community, I think that the story about the pipeline and why we don't need the pipeline in Iowa or why the pipeline should be stopped in total or why we should stand with Standing Rock has evolved over these past few years. It'll be interesting to see how that community evolves now that the pipeline is in the ground but there's no oil flowing through it yet. Probably there will be more pipelines coming now that the company has this easement across our state (update: oil began flowing through the Dakota Access pipeline as of June 2017).

GOETTLICH: You've mentioned the protectors at Standing Rock. They've received some public attention in their efforts to stop the Dakota Access Pipeline. To what degree have Native and nonNative groups worked together to resist the pipeline extension through Iowa?

CARTER: We started in Iowa organizing resistance to the pipeline in the fall of 2014. That fall members of the Meskwaki Settlement in Iowa, which is unique because they do not live on a reservation but bought their land back from the state, began doing work inspired by their own concerns about the Dakota Access Pipeline. It passes just south and east of their settlement but passes under rivers and streams that are important to them. They consider Iowa their home and their homeland. It's going through Iowa, and so it was a concern to them. We started organizing--there would be rallies, or there would be public testimony at hearings — and the Meskwaki would be there also giving voice to their concerns about this pipeline.

Spring of 2016 is when Standing Rock started the first camp at Sacred Stone. That summer of 2016, members of the Meskwaki tribe ran with Standing Rock youth to DC to deliver petitions to the US Army Corps. There has always been a relationship with the Meskwaki in Iowa in this fight and then also with the Standing Rock tribe and working in a very reciprocal way to share knowledge and resources about what is happening.

In August 2016, Christine Nobiss formed a group called Indigenous Iowa, largely inspired by Standing Rock and what has been happening around the Dakota Access Pipeline fight in Iowa. 
They have helped to start a camp near Williamsburg, Iowa. Just this past week they put out a call for people to come, and a lot of resources from Standing Rock have come down there. They've moved building materials and things down, and people who had been up at Standing Rock have come down too. LaDonna Allard, who was really influential in establishing the Sacred Stone camp, it was on some of her family's land, came down last week, and Christine Nobiss had spent a lot of time up at Standing Rock (update: the camp has since disbanded, but the group continues their work).

What we're seeing is all along this pipeline path, a lot of community building and organization not just at local levels but also at this larger regional level, which I think is really an important shift in social movements addressing extractive energy in the United States that have historically been very localized. Now we're seeing this kind of regional coalescence of organizations, of the Native community, of the farmers and ranchers coming out Keystone, all of these groups working together, sharing resources, being on conference calls. I think that, yes, Dakota Access put their pipeline in the ground, but there is this positive thing that's come out of it where people have learned a lot through this project and learned a lot through this process and working together.

That's really important, because the oil companies are putting these pipelines where resistance is the least. Being able to create resistance quickly and share these resources quickly is really important in the timing of these projects and is something that can be moved around the country. It's already being moved around the Midwest among the Keystone fighters, the Dakota Access fighters. Then also, Enbridge had had the Sandpiper Pipeline that Winona LaDuke's Honor the Earth had been fighting, going from the Bakken region over to the Great Lakes. It was going to go through their tribal rice lands. They have been fighting the Sandpiper Pipeline for years. Well, Enbridge dropped its plans, which was a great win in that fight, but because of that Enbridge invested in Dakota Access.

It's really clear to the resistors and the water protectors and the pipeline fighters, whether they identify as Native or ranchers or farmers or just everyday residents of these towns, that it needs to be an effort that is growing and evolving and sharing resources and focusing on that expansion of community in this bigger sense, 
beyond state borders, beyond town borders, beyond even the specific pipeline fight.

GOETTLICH: The effects of changes to the environment globally or local projects very much may be what $C$. Wright Mills would call a public issue or, on the other hand, that could be addressed in the ways that Michael Burawoy has talked about in terms of public sociology. Nonetheless, public sociology is a term that's been in circulation for some time but suffers perhaps from a bit of ambiguity of meaning. What does public sociology mean to you as a practicing sociologist?

CARTER: I consider public sociology to be making our science public; that as scientists, we are communicating our science with the public; that our science is a public good; that its process is public, so there's transparency in process. Our funders are public. The goods that come out of it are public. It's serving the community, and from that baseline definition of public sociology, I also identify as a feminist sociologist and am looking at questions of inequity and justice and trying to center justice in my work as a public sociologist.

I think perhaps my public sociology is more political than that of others, but public sociology doesn't only study or engage in social movements. I would say all of our sociology is political. I have friends that who for every journal article they're publishing, they're also writing a blog or writing a letter to the editor, making sure that they're being really purposeful about sharing their science and what they're learning in a way that's accessible to the public.

GOETTLICH: You recently wrote a piece for the Union of Concerned Scientists about the March for Science in response to concerns published elsewhere that the march would be a compromise of scientific objectivity. What's your position on that?

CARTER: I think the March for Science is great and needed, and I plan to take part as a sociologist, as a citizen, as a human being alive on this planet as it's being compromised every day by private corporate interests. I don't think that there's anything in that that compromises my science. I just don't think that's an issue at all. This chorus that I hear, though, of scientists, even social scientists, 
saying, "Yes, it's important that we are engaging with the public and that we do a better job communicating our science with the public" is usually followed by this, "But, we don't want to politicize science. We don't want to water down our science.” It's this really privileged, elitist view, I think, of what we're doing.

I don't think sharing science with the public or doing science for the public is watering anything down. I think it's harder. It's messy like the social world is, and we try to create some order out of the process that we make to do our work. I think it's really exciting and very much needed right now. I make the case that there's a long history from Rachel Carson to sociologists like Kari Norgaard, who studies climate change denial, and upon publication of her book was personally targeted and attacked by Rush Limbaugh and the religious right. We see people doing sociology, people doing science, public science all the time who get attacked by the people who are profiting over people not knowing about these things.

That's going to continue to happen, but I think people are afraid of that because they're afraid of what that'll mean for their reputation; they're afraid for what that'll mean to their position at their universities. I understand that that fear is real, but there is consequence to what we do. I mean, there's consequence in any job to what you do or what you don't do, but there's a power, I think, in being together and framing it as this is what we're doing as scientists. It's not an individual action, it's a collective action. There's some power in that. I hope that it helps shift some of this debate about what science should be or for whom science should be done.

GOETTLICH: Normatively speaking, should sociology become more involved in public projects? If so, why and/or how do you see this happening already?

CARTER: I do see it happening already. My concern with it is that we want sociology to be involved in public projects, in all projects, but at the front end, at the beginning of projects rather than being brought in at the end, which takes a lot of work among ourselves as scientists across disciplines. I don't think we're trained to do that very well. We still exist in silos on our campuses, but it has been encouraging to see-and we don't know what the future with this 
will be--that more of the federal funding call for proposals have required the natural or biological science teams to include social science as part of their teams in these projects. But again, we need to be there as equal players in the project, not as something that's added on at the end.

There are people who are really good at marketing and design and journalism and public communications, but sociology is something different than that. If people just need brochures or something done, that's a different sort of person. A sociologist can help to ask, should we even spend all of this money developing this technology; is that what this community needs at this time? What might they need? What might we try? They're really important to have at the starts of projects.

I think if we do a better job as sociologists at making our benefit and our use known and public, then maybe that will be easier, because people won't see us as existing only in a theoretical realm. They'll understand it's actually very expensive to not include sociologists on a project and to have to go back and figure out something later. The problems that we have are all pretty wicked ones with climate change and social inequality and these things, and we have a lot that we can offer, I think, in those community-level changes.

GOETTLICH: Donna Haraway has famously discussed feminist objectivity and the privilege of partial perspective regarding science. What does that mean to you in practical or methodological terms?

CARTER: I think in the community-based research I do, I guess I try to create methodologies that are practical, and so it's kind of a fused answer here. I'm very conscious of my positionality as a researcher and what I'm bringing to these experiences. The work that I have been doing, I've been very fortunate and humbled to be doing this work in a community where I grew up. I know the histories of these places and the people I'm working with in a very intimate way. It's part of my own story. There's a lot of people in the community that I'm studying whom I love. They're my family, they're my friends, these places I love, and so I'm very connected to what I have been studying. 
I think there are good things and bad things about that in terms of strengths and weaknesses in research and what I can see or not see and what people see or don't see when they're working with me in terms of research, but it has given me a lot of opportunity to have ins to certain discussions with farmers, to build trust with communities who may not normally trust people coming from the university or trust sociologists or trust people who have written, like I've written, letters to the editor about how I think the Dakota Access Pipeline is a really bad idea.

I think it's just always something that we're negotiating as researchers, and I would hope whether people identify as feminist sociologists or not or whether they're using feminist research methods or not, we have to navigate these things and acknowledge these things in the research that we're doing, especially with qualitative research and community-based research, for sure with participatory research. I'm not interested in having to just explain or defend the methodologies I've used in terms of objectivity or empiricism, because those are such constructed standpoints already, like for whom, why.

In my research, I've been questioned because I have spent a lot of time studying gender in agriculture and focusing on women in agriculture and have had people say, "Yes, but you're leaving the men out now, so how balanced, how objective is your research if you're only researching the women?” To which I can respond, "Well, for 150 years Iowa State has researched the men. We have tons of research about that." Go to the library, you can get many articles. That is there. We know that. I'm absolutely comfortable with why I'm researching the women. When they ask me, "Do you want to interview my husband, too or my brother, too?” I just am very honest in saying, "There's been a lot of research done already about men in agriculture.” They're like, “Oh, yeah, I guess you're probably right."

I don't go into it saying, “This is a feminist project.” I'm sure that a lot of the women I have met and befriended through my research do not identify as feminists and would not want to identify as feminists, and I think that's fine, but that we're talking about the importance of lifting up their story really resonates with them; as women, it really resonates with them. That's what concerns me, I think, in my research, that it makes sense to the people I'm working 
with more so than trying to defend it to people that have questions about it.

GOETTLICH: In your work on the pipeline, you've used a method called photovoice. Tell me about it, what it is, how you came to choose it and how you see it affecting the outcomes or the product of your research.

CARTER: I had read Shannon Elizabeth Bell's ethnography, Our Roots Run Deep as Ironweed, which is about women in Appalachia who have fought mountaintop removal in their communities, these horrible stories about how it's changed their lives, the health of their children, futures of their towns, these sorts of things. In this project, Bell used photovoice. She asked these women to take pictures of their community, and I found it really powerful to read the participants' accounts about what they were seeing in their community in their own words, through their own images.

I thought, wouldn't it be interesting to apply that to this crisis that we're seeing right now in Iowa with water quality? It's not a very visible problem, unlike what Bell was studying in Appalachia. Mountaintop removal is very visible, very violent, easy to see, but the pollution of water in Iowa is very hard to see because if it's really polluted water, it looks really clean because there's nothing living in it. I thought I would try to get some money to use photovoice.

I had been doing a dissertation project studying women farmland ownership and conservation adoption and got a little bit of money from the Leopold Center for Sustainable Agriculture in Iowa and some sponsorship from community-based organizations in that watershed and then a small fellowship through Toyota TogetherGreen by Audubon. I wasn't sure what would happen. Doing photovoice, you recruit people and whether you have four people, or you have 14 people, it doesn't matter because you're not trying to create a generalizable story. The whole point is you're trying to lift up a story that's maybe not seen or is taken for granted, that people are just dismissing. It's telling a story or many stories from the watershed.

We had six participants from the Raccoon River watershed, which is the most polluted watershed in Iowa. A couple of them knew each other from before the project, but they were mostly new 
to each other. They had all different types of farmland. Some of them were focused only on conservation. Some of them had traditional corn and soybean farms. Politically, they were different. Age-wise, they were different. They were all white women, but it was a pretty good diversity of landowners for Iowa, given the historic settlement of land in Iowa. With photovoice, you start with a prompt, and the prompt was to tell the story of the watershed, which is very broad.

The women came together for our first meeting, and I talked about what makes a good picture, how to use your camera phone to take pictures, showed examples from Bell's project in Appalachia, showed that they didn't need to have a novel for each picture. Just a couple sentences would be fine, a paragraph would be fine. It was really open to what they wanted to do. It was really broad, and it was hard because they're used to somebody coming in and telling them, "We're doing this project. You need to do this. Come back with that. Here's your homework." I think that's how we're all maybe educated, so it was hard to remain the facilitator and not try to lead them down a specific path.

When we came back to the second meeting then, they brought pictures. They all brought pictures of the prairie in bloom or monarch butterflies or the badger they had seen in the field or the frog on the leaf, really beautiful nature pictures. Using photovoice at the second meeting is recommended that you ask questions, what stories do we see here; what stories don't we see here? They saw lovely stories, and they said, "But we don't see any people, and we don't see the ugly things. Can we take pictures of those too?" I was like, "Sure. We need to get permission forms if you take pictures of people, but if they're okay with it, then yeah, you can take pictures of people, and yeah, it's okay to take pictures of things that you're worried about or concerned about."

When we came back together for the next meeting, one woman had some pictures of some dead hogs that were out in the trash bin, a large bin outside of her neighbor's hog confinement. One woman had a picture of a barn that was falling down that she remembered as a child had been a really beautiful barn. She wrote this short narrative about just the changes that families don't live on these properties anymore, and there's been this exodus of people from that community. People took pictures of erosion, really bad erosion on neighbors' fields. 
This next time they came together, it was the doom and gloom that they took the pictures of. We had a lot of pictures. We can't possibly use all of them, but I asked them, "What story do you want to tell, and how do you want to tell it?" They said, "Well, what if we all..." They decided everyone should pick five or six or seven pictures to focus on and to come back together again. People narrowed all their pictures down. We came back again, and we from those pictures could see a collective story of the watershed about, there were some pictures about changes in season cycle. There were changes about population of the community, changes in terms of ecological destruction or restoration.

People felt like, okay, we're starting to see some themes here that are emerging. Then they wanted to share them because they thought they looked really good. They decided they wanted to do a public gallery opening in the community in the center of that watershed, to host it and invite everybody from the public. I had funds to do some advertising for it. They told me which papers to use. I started a guest list for it. They told me which soil and water district commissioners to invite or city managers, people like this. We made the guest list. Then the project was done.

That was what the grant was for, and we'd gone through the cycle of a photovoice project, but they now almost a year later are still taking it places. They're saying, "Hey, this arboretum wants to show it. Is that okay?" or, "We can put it up for two months at Reiman Gardens in Iowa State. Is that good? Can I bring it to this conference I'm going to?” There have been a lot of opportunities to take these 26 two-foot by three-foot boards and 26 easels, it's a lot of stuff, to different community events across the state, and they're really proud to share these.

I wasn't sure. Sometimes with photovoice projects people, they're there for the process, but they don't really want to share it in a public way, which is fine. It's not an obligation, but all of them did want to share their work. I think they found some sort of power in it together. It's been really exciting to see that continue on, to see the discussion continue on. We created a listserv, so now they're sharing. If they write a letter to the editor or something, they send it to our group. They talk about how they miss meeting together, because we always met together at a renovated old hotel that had this neat restaurant. They would all order drinks. For them, it was a fun 
time to get away to talk about things that were really interesting to them that they didn't really have space to talk about other places, and they would make it fun. They wanted to hang out there and talk with each other.

Their group has continued on, and they still ask me, "Can we do this?” I always say, "Whatever, it's yours. You can do it. I'll try to help you how I can." The most recent question was, "Can we train other people on how to do this?” I was like, "Sure, if you want. It's not a proprietary process." They're really interested in sharing this process with people at their Rotary Clubs or other groups that they're members of, so we will see. It's really small. It was only six women, but the idea with photovoice is that the potential influence is exponential because you're sharing it around in communities or online through different types of social media or however people want to share it. It inspires people to see that, oh, maybe my story is significant too.

There's not a good way to measure that, and it's just through anecdotal evidence that I hear. A colleague came up after the Blackmar Lecture and said that he had seen one of the project participants give a slideshow of all of the display boards at a meeting that he had been at in Iowa the other weekend. You just don't know where it goes and how, but it was something that was really fun to do after my dissertation research that I think I had a lot of flexibility in because I was able to get some funding to do it. It took a lot of time, because it's a lot of meeting with people and a lot of process work, and it doesn't end.

If it goes well, it continues on, but I like that. As a public sociologist, a feminist sociologist who's really interested in placebased methods and place-based research questions, I really loved how I could see it change the stories the women were telling and what they thought about in terms of their place in their watershed.

GOETTLICH: It sounds like it's a real intersection of feminist methodology, of public sociology, and community building in a way that's dynamic and grows outside of your influence as a researcher. I'm going to shift gears here and ask about teaching a little bit. Your research addresses issues that may be politically challenging to students. What's your philosophy on teaching, especially as a form of praxis? 
CARTER: I read bell hooks' Teaching to Transgress, and that was really influential to me in thinking about teaching as a form of praxis and, of course, thinking about the history of resistance within universities and institutions and institutional change and wanting to feel like I had some agency in places where it may not seem like we have a lot of power, perhaps. I think it's really inspiring teaching that way. As an instructor, for me, it's very fun. I think it's maybe scary in the beginning.

I remember teaching first at Iowa State environmental sociology, and I had a lot of students who were from traditional ag backgrounds and wanting to make sure that they would listen to me and not tune me out and write me off as an environmentalist or as an activist. I remember feeling the first few weeks that maybe I came across really boring. But I think when we think about the most influential teachers, it's because they were really passionate about things, and they were sharing that with you and inspiring that with you. I just decided to risk it and try to be that person, too.

I really love teaching about environmental social problems right now. There are so many that I think even for students who aren't sociologists or aren't going into the social sciences, it's important for them to understand how these are also social questions. At Iowa State I had ag engineering students in my classes, and they could take something from that and see, yes, because human beings are going to be using the technology I'm developing, and the way people are farming is changing, and it's because of these environmental problems. I think that's great that they can do that. I think in sociology we have maybe an easier time than some of the other disciplines. Because we are all social creatures, this stuff that we're talking about should apply in different ways to students' lives.

The political part has been difficult, I think, especially this presidential election, I've been cautious. I notice that I spend more time at the start of each term talking about what respectful participation means and what this class will be about and what will not be allowed in the room; that disagreement is great and encouraged, as long as it's constructive and respectful, it's welcome, and that people can call me out for things too. I haven't had any trouble, and I don't know, maybe I've just been lucky, but since 


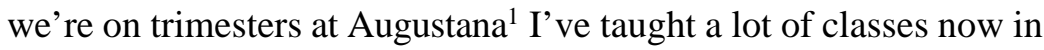
the past two years. I know that there are some students with whom I would be on very different sides of the spectrum when it came to politics, but I am hoping that some of these things they're seeing in ways like, oh, that's why people are talking about it that way or whatever it is and able to take something from it that's useful.

For my upper division classes, students are self-selecting and enroll in upper division sociology classes because they have some interest already. I've found that especially during winter term and with the inauguration, that those courses really became havens and sort of protected spaces for the students in them. I've never had a time with so many students who've cried in class, who've been just so honest in class. I mean, I've taken days where we just didn't even talk about the things that were on the syllabus, and we're talking about what happened in the news today or what happened in the news yesterday; asking "What does that mean for us?" The students will say, "Oh, we're so sorry we hijacked your class with these things," but these are sociological questions, so I don't feel like the class is getting hijacked in any way.

I think being flexible in that way is really important for those of us that have this power, that we have a classroom and we have a space, that we share that in different ways with the students when it's needed. I'm learning a lot from the students, too. I've definitely had a number of students I've thought about whom I think that they should be teaching the class today because they're in places where they're newly radicalized. They're really reading a ton of feminist theory, and they're so excited about it. I think that's great. That's really powerful, and that place is a little further away from me now, so creating space for them to share that is important.

GOETTLICH: We have time for one last question. Is public sociology or activism a risk for early career scholars? From your experience or from your perspective, how do you suggest navigating these risks if you do agree that they're there?

\footnotetext{
${ }^{1}$ Dr. Carter's appointment at the time of this interview was at Augustana College in Rock Island, IL.
} 
CARTER: It absolutely is a risk, especially now that everything's recorded, and everything lives online everywhere now. You go to any rally or any letter that I've ever written to a newspaper, it's out there in the world. For me, it was right for me to make a decision early on to just own that. I didn't like Twitter in the beginning but created a Twitter handle to just show that this is who I am as a scholar, and this is the type of stuff I'm studying; I'm active in it, and this is the discussion I'm in, and just be really upfront about it. Yes, that means there's certain projects I will never be a part of, and it means that there are certain jobs I wouldn't be considered for, but then I don't know that I would've been happy in those projects or jobs anyway, because it's such a central part of my identity that I wouldn't want to be hiding it.

It's not as if I was interested in trying participatory methods once and then I checked it off a box and now I'm done. That's the type of work I want to do in my career, so that's not welcome in a lot of places. Like I've shared, it takes a lot of time. It may not bring in the big money. So, I think it is a risk, but I think a lot of what we do right now is really risky as sociologists, the questions that we're studying.

Every day different things are being called into question that haven't been called into question before. It may seem really clear right now for some people that these things are risks, but I think unfortunately, in a couple years down the road, even though scientists who think that they're very safe in studying what they're studying, they're going to be realizing that their science also is very political and joining the same discussion that's been going on for a while now, too.

I think it's just going to increase that people realize as scientists, as sociologists, whether people identify as public scientists or not, that the public's going to start asking for either more information or calling into question your research, if it has value, and what value it has. Then we're going to have to respond if you want to continue to do the work that you're doing. I think it's something that people need to put a lot of thought into in terms of what path they want to have and what kind of job they want to have, but we're all doing that early on.

As we choose our dissertation research projects, our advisors are telling us, "You want to choose something that you're going to be 
really interested in because you're going to be in this for a long time, and in your first job is going to be research that's coming out of your dissertation work. You want to choose something you're committed to.” I think we're already thinking about these questions of future and the types of scholars we want to be really early on in our career. I don't think it's any different for people who are thinking about public sociology or activism.

GOETTLICH: Thank you very much, Dr. Angie Carter, for coming to $\mathrm{KU}$ as the 2017 Blackmar Lecturer, and for doing this interview. It's been a real pleasure.

CARTER: Thank you. 